medRxiv preprint doi: https://doi.org/10.1101/2021.07.16.21260618; this version posted July 22,2021 . The copyright holder for this preprint

(which was not certified by peer review) is the author/funder, who has granted medRxiv a license to display the preprint in perpetuity.

\title{
1 Antibody titers measured by commercial assays are correlated with neutralizing
}

\section{2 antibody titers calibrated by international standards}

3 Yu-An Kung a, ${ }^{\mathrm{a},}$, Chung-Guei Huang ${ }^{\mathrm{c}, \mathrm{d},{ }^{*}, \text { Sheng-Yu Huang }}{ }^{\mathrm{a},{ }^{*}, \text { Kuan-Ting Liu }}{ }^{\mathrm{a}, \mathrm{b},{ }^{*}, \text { Peng- }}$

4 Nien Huanga,e, Kar-Yee Yu ${ }^{\mathrm{a}, \mathrm{b}}$, Shu-Li Yang ${ }^{\mathrm{c}}$, Chia-Pei Chen ${ }^{\mathrm{c}}$, Ching-Yun Cheng ${ }^{\mathrm{c}}$,

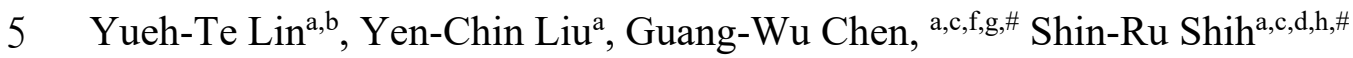

$7 \quad{ }^{a}$ Research Center for Emerging Viral Infections, College of Medicine, Chang Gung

8 University, Taoyuan, Taiwan

9 b Graduate Institute of Biomedical Science, College of Medicine, Chang Gung

10 University, Taoyuan, Taiwan

11 c Department of Laboratory Medicine, Linkou Chang Gung Memorial Hospital,

12 Taoyuan, Taiwan

$13{ }^{\mathrm{d}}$ Department of Medical Biotechnology and Laboratory Science, College of Medicine,

14 Chang Gung University, Taoyuan, Taiwan

15 e Division of Infectious Diseases, Department of Pediatrics, Linkou Chang Gung

16 Memorial Hospital, Taoyuan, Taiwan

$17{ }^{\mathrm{f}}$ Artificial Intelligence Research Center, Chang Gung University, Taoyuan, Taiwan 
medRxiv preprint doi: https://doi.org/10.1101/2021.07.16.21260618; this version posted July 22,2021 . The copyright holder for this preprint

(which was not certified by peer review) is the author/funder, who has granted medRxiv a license to display the preprint in perpetuity. All rights reserved. No reuse allowed without permission.

$18 \mathrm{~g}$ Department of Computer Science and Information Engineering, School of Electrical

19 and Computer Engineering, College of Engineering, Chang Gung University, Taoyuan,

20 Taiwan

$21{ }^{\mathrm{h}}$ Research Center for Chinese Herbal Medicine, Research Center for Food and

22 Cosmetic Safety, and Graduate Institute of Health Industry Technology, College of

23 Human Ecology, Chang Gung University of Science and Technology, Taoyuan,

24 Taiwan

25

$26{ }^{*}$ Corresponding author

27 Guang-Wu Chen, Ph.D. (E-mail: gwchen@mail.cgu.edu.tw)

28 Department of Computer Science and Information Engineering, Chang Gung

29 University, Taiwan

30 Mailing address: No.259, Wenhua 1st Rd., Guishan Dist., Taoyuan City, Taiwan

31 Phone: $+886-3-2118800$ ext.3368

32

33 Shin-Ru Shih, Ph.D. (E-mail: srshih@mail.cgu.edu.tw)

34 Research Center for Emerging Viral Infections, Chang Gung University, Taoyuan,

35 Taiwan

36 Mailing address: No.259, Wenhua 1st Rd., Guishan Dist., Taoyuan City, Taiwan

37 Phone: $+886-3-2118800$ ext.5497

$38 *$ These authors contributed equally to the study.

39 Running title: Correlation between IU value of NAb and Ab titer 
medRxiv preprint doi: https://doi.org/10.1101/2021.07.16.21260618; this version posted July 22,2021 . The copyright holder for this preprint

(which was not certified by peer review) is the author/funder, who has granted medRxiv a license to display the preprint in perpetuity.

\section{Abstract}

41 The World Health Organization (WHO) has highlighted the importance of an

42 international standard (IS) for SARS-CoV-2 neutralizing antibody titer detection, with

43 the aim of calibrating different diagnostic techniques. In this study, IS was applied to

44 calibrate neutralizing antibody titers $(\mathrm{IU} / \mathrm{mL})$ and binding antibody titers $(\mathrm{BAU} / \mathrm{mL})$ in response to SARS-CoV-2 vaccines. Serum samples were collected from participants receiving the Moderna $(n=20)$ and Pfizer $(n=20)$ vaccines at three time points: pre-

47 vaccination, after one dose, and after two doses. We obtained geometric mean titers of 1404.16 and $928.75 \mathrm{IU} / \mathrm{mL}$ for neutralizing antibodies after two doses of the Moderna

49 and Pfizer vaccines, respectively. These values provide an important baseline for

50 vaccine development and the implementation of non-inferiority trials. We also

51 compared three commercially available kits from Roche, Abbott, and MeDiPro for the

52 detection of COVID-19 antibodies based on binding affinity to S1 and/or RBD. Our

53 results demonstrated that antibody titers measured by commercial assays are highly

54 correlated with neutralizing antibody titers calibrated by IS. 
medRxiv preprint doi: https://doi.org/10.1101/2021.07.16.21260618; this version posted July 22,2021 . The copyright holder for this preprint

(which was not certified by peer review) is the author/funder, who has granted medRxiv a license to display the preprint in perpetuity.

\section{Introduction}

57 Identifying immune correlates of protection against SARS-CoV-2 infection is

58 challenging. Neutralizing antibody titer is not the only determinant of vaccine efficacy;

59 however, the neutralization level is highly predictive of immune protection (1-3).

60 Moreover, the detection of neutralizing antibody titers is feasible in many laboratories.

61 Several methods have been developed to measure neutralizing antibody titers in

62 convalescent serum or vaccinated serum, such as plaque reduction assays, focus

63 reduction assays, microneutralization assays using real viruses, and pseudovirus assays

$64(4,5)$. These assays differ substantially, including variation in protocols for similar assay types and variation among laboratories $(6,7)$.

672 neutralizing antibody titer detection is a key goal of the World Health Organization

68 (WHO). Various standards, such as 20/130 and 20/136 (provided by National Institute

69 for Biological Standards and Control [NIBSC]), are widely used to establish a baseline

70 for comparing neutralizing antibody titers from different datasets (different laboratories,

71 protocols, assays, etc.) (6). An IS is based on pooled human plasma from convalescent

72 patients (8). For different pooled cohorts, different standard sera are obtained, each with

73 predetermined international units (IU) for the conversion of neutralizing antibody titers,

74 enabling immunogenicity characteristics to be correctly compared across laboratories 
medRxiv preprint doi: https://doi.org/10.1101/2021.07.16.21260618; this version posted July 22,2021 . The copyright holder for this preprint

(which was not certified by peer review) is the author/funder, who has granted medRxiv a license to display the preprint in perpetuity.

All rights reserved. No reuse allowed without permission.

75 and vaccine developers. Although many laboratories have applied IU to present

76 neutralizing antibody titers in the serum of patients with COVID-19 or vaccinated

77 individuals, reference data are insufficient.

78 Furthermore, neutralization tests using real viruses at biosafety level 3 (BSL-3)

79 laboratories are laborious and time-consuming. Binding assays based on the anti-spike

80 protein or anti-receptor binding domain (RBD) are widely used to measure neutralizing

81 antibodies (9-11). However, the correlation between antibody titers from binding assays

82 (binding antibody unit, BAU) and neutralizing titers (IU) has not been clearly

83 established.

In this study, 120 serum samples from 40 total subjects were analyzed (20 subjects receiving Moderna vaccines and 20 subjects receiving the Pfizer vaccines) before

86 vaccination, after the first dose, and after the second dose to estimate the correlation

87 between titers estimated by a microneutralization assay using real viruses in a BSL-3

88 laboratory (IU/mL) and antibody titers measured by anti-S1 and anti-RBD enzyme-

89 linked immunosorbent assay (ELISA) (BAU/mL). Several promising vaccine

90 candidates have undergone different phases of clinical trials (12). Our results provide

91 useful information for comparisons of neutralizing antibody titers with those of other

92 widely used vaccines and for non-inferiority trials.

93 
medRxiv preprint doi: https://doi.org/10.1101/2021.07.16.21260618; this version posted July 22,2021 . The copyright holder for this preprint

(which was not certified by peer review) is the author/funder, who has granted medRxiv a license to display the preprint in perpetuity.

Materials and Methods

\section{Serum samples collection}

A total of 120 COVID-19 vaccinated sera were purchased from Access Biologicals

(Vista, CA, USA). The serum samples were collected and followed by protocol SDP-

003, Human Biological Specimens Collection, data September 22, 2017 and the

qualifications of Principle Investigator (Robert Pyrtle, M.D.) were reviewed and

100 approved by Diagnostics Investigational Review Board (Cummaquid, Massachusetts,

101 USA). The protocol SDP-003 will expire on May 3, 2022. The collection dates of the

102 sera were between February 25, 2021 to April 29, 2021. The serum from 20 individuals

103 vaccinated with Moderna mRNA-1273 and 20 individuals vaccinated with Pfizer

104 BNT162b2 were collected before vaccination, after the first dose, and after the second

105 dose. The ages of the vaccinated participants are between 22 to 69 years old.

107 Cell culture and virus

108 African green monkey kidney (Vero E6) cells (CRL-1586) were purchased from the

109 American Type Culture Collection (ATCC, Bethesda, MD, USA) and maintained in

110 Dulbecco's modified Eagle's medium (DMEM; Gibco, Waltham, MA, USA)

111 containing $10 \%$ fetal bovine serum (FBS; Gibco) at $37^{\circ} \mathrm{C}$. Severe acute respiratory 
medRxiv preprint doi: https://doi.org/10.1101/2021.07.16.21260618; this version posted July 22,2021 . The copyright holder for this preprint

(which was not certified by peer review) is the author/funder, who has granted medRxiv a license to display the preprint in perpetuity.

All rights reserved. No reuse allowed without permission.

112 syndrome coronavirus 2 isolate SARS-CoV-2/human/TWN/CGMH-CGU-01/2020

113 was used in the live virus microneutralization assay.

115 Live virus microneutralization assay

116 Vero E6 cells $\left(2 \times 10^{4}\right.$ cells per well $)$ were seeded in a 96-well plate and incubated at

$11737^{\circ} \mathrm{C}$ for $24 \mathrm{~h}$. The medium was replaced with $100 \mu \mathrm{L}$ of fresh DMEM containing $2 \%$

118 FBS. The live virus microneutralization assay was performed in a BSL-3 laboratory

119 using the SARS-CoV-2/human/TWN/CGMH-CGU-01/2020 strain. All serum samples

120 were heat-inactivated at $56^{\circ} \mathrm{C}$ for $30 \mathrm{~min}$ and then 2-fold serially diluted in DMEM

121 (Gibco) without FBS. From a starting dilution of 1:8 for each sample, ten 2-fold

122 dilutions were performed for a final dilution of 1:8192. Each serum sample was

123 incubated with 100 50\% tissue culture infectious doses (100 TCID50) of SARS-CoV-

1242 at $37^{\circ} \mathrm{C}$ for $1 \mathrm{~h}$ prior to infection with Vero E6 cells. Add $100 \mu \mathrm{L}$ of the virus-serum

125 mixtures at each dilution to a 96-well plate containing the confluent Vero E6 monolayer.

126 After infected cells were incubated at $37^{\circ} \mathrm{C}$ for 5 days, they were fixed with $10 \%$

127 formaldehyde and stained with crystal violet. The neutralization titer was calculated as

128 the logarithm of the $50 \%$ end point using the Reed-Muench method based on the

129 presence or absence of cytopathic effects. Each serum sample was tested in four 
medRxiv preprint doi: https://doi.org/10.1101/2021.07.16.21260618; this version posted July 22,2021 . The copyright holder for this preprint

(which was not certified by peer review) is the author/funder, who has granted medRxiv a license to display the preprint in perpetuity.

All rights reserved. No reuse allowed without permission.

130 replicates. Geometric mean titers (GMTs) were calculated with 95\% confidence

131 intervals (CIs) using GraphPad Prism version 8 (GraphPad Software, Inc., CA, USA).

\section{ELISA}

134 For indirect ELISA, a 96-well plate was coated with $2 \mu \mathrm{g} / \mathrm{mL} \mathrm{S1,} \mathrm{RBD,} \mathrm{and} \mathrm{N} \mathrm{protein}$

135 (Sino Biological, Beijing, China) diluted in phosphate-buffered saline and incubated

136 overnight at $4^{\circ} \mathrm{C}$. Each well was blocked with $300 \mu \mathrm{L}$ of StartingBlock ${ }^{\mathrm{TM}}$ T20 blocking

137 buffer (Thermo Fisher Scientific, Waltham, MA, USA) for $1 \mathrm{~h}$ at $37^{\circ} \mathrm{C}$. Serum from

138 vaccinated donors or NIBSC 20/136 standard was diluted in blocking buffer, and 100

$139 \mu \mathrm{L}$ of the sample was added to a 96-well plate, followed by incubation for $1 \mathrm{~h}$ at $37^{\circ} \mathrm{C}$.

140 After washing, horseradish peroxidase (HRP)-tagged anti-human antibodies (Abcam,

141 Cambridge, UK), diluted 1:10,000 in blocking buffer, were added to the wells (100

$142 \mu \mathrm{L} /$ well), and the plate was incubated for $1 \mathrm{~h}$ at $37^{\circ} \mathrm{C}$. Samples with $\mathrm{N}$ antibodies were

143 incubated for $30 \mathrm{~min}$ at $37^{\circ} \mathrm{C}$. The chromogenic reagent 3,3,5,5-tetramethylbenzidine

144 (TMB) was mixed with an equal volume of Color A and B (R\&D Systems, Minneapolis,

$145 \mathrm{MN}, \mathrm{USA}$ ). The TMB reaction time for $\mathrm{S} 1$ and RBD ELISA was $5 \mathrm{~min}$ and for $\mathrm{N}$

146 protein ELISA was $10 \mathrm{~min}$. After the reaction, stop solution (R\&D Systems) was added

147 to the wells, and the absorbance was measured immediately at $450 \mathrm{~nm}$ using a Synergy

1482 Microplate Reader (Bio-Tek, Winooski, VT, USA). 
medRxiv preprint doi: https://doi.org/10.1101/2021.07.16.21260618; this version posted July 22,2021 . The copyright holder for this preprint

(which was not certified by peer review) is the author/funder, who has granted medRxiv a license to display the preprint in perpetuity.

\section{Serologic assay}

150 Each serum sample was analyzed by the MeDiPro SARS-CoV-2 antibody ELISA,

151 Roche Elecsys ${ }^{\circledR}$ Anti-SARS-CoV-2 S assay, and Abbott AdviseDx SARS-CoV-2 IgG

152 II assay, according to the manufacturers' instructions. The MeDiPro SARS-CoV-2

153 antibody ELISA detected antibodies against S1 and RBD, and values $<34.47 \mathrm{IU} / \mathrm{mL}$

154 were considered negative. The electrochemiluminescence immunoassay (ECLIA) (i.e.,

155 Roche Elecsys Anti-SARS-CoV-2 S assay) was used for the detection of antibodies

156 against the RBD of $\mathrm{S}$ protein; $<0.80 \mathrm{U} / \mathrm{mL}$ was considered negative and $\geq 0.80 \mathrm{U} / \mathrm{mL}$

157 was considered positive for anti-SARS-CoV-2 S protein. The Abbott AdviseDx SARS-

$158 \mathrm{CoV}-2$ IgG II assay is a chemiluminescent microparticle immunoassay (CMIA) for the

159 detection of IgG antibodies to the RBD of S protein; the cut-off value was $50.0 \mathrm{AU} / \mathrm{mL}$.

161 WHO international standard unit (IU) conversion

162 WHO IS sera $(20 / 130,20 / 136$, and 20/268) were obtained from NIBSC. The 50\%

163 neutralization titer $\left(\mathrm{NT}_{50}\right)$ values for WHO IS sera were determined by a live virus

164 microneutralization assay (Supplementary Table 1). Each standard serum sample was

165 tested in duplicate, except 20/130. 
medRxiv preprint doi: https://doi.org/10.1101/2021.07.16.21260618; this version posted July 22, 2021. The copyright holder for this preprint (which was not certified by peer review) is the author/funder, who has granted medRxiv a license to display the preprint in perpetuity. All rights reserved. No reuse allowed without permission.

\section{Statistical analysis}

169 Statistical analyses were performed using GraphPad Prism version 8 (GraphPad

170 Software, Inc., CA, USA). Pearson's correlation coefficients $(r)$ were used to determine

171 the correlation between the titers obtained by the different serological assays and the

172 live SARS-CoV-2 NT assay. Statistical significance was set at $P<0.05$.

173 
medRxiv preprint doi: https://doi.org/10.1101/2021.07.16.21260618; this version posted July 22,2021 . The copyright holder for this preprint

(which was not certified by peer review) is the author/funder, who has granted medRxiv a license to display the preprint in perpetuity.

\section{Results}

175 The neutralizing antibody titer is important for evaluating protection against viral

176 infection after vaccination. Dynamic neutralizing antibody titers were observed in

177 individuals who had been fully vaccinated. In detail, we obtained serum samples from

17820 individuals vaccinated with Moderna mRNA-1273 and 20 individuals vaccinated

179 with Pfizer BNT162b2. For each of these 40 individuals, serum samples were collected

180 before the first dose, 24 days after the first dose from Moderna or 14 days after the first

181 dose from Pfizer, and 14 days after the second dose. A total of 120 serum samples were

182 tested to determine neutralizing antibody titers by a live SARS-CoV-2 virus

183 microneutralization assay. We obtained the $\mathrm{NT}_{50}$ values that represent $50 \%$ protection

184 against SARS-CoV-2-induced cell death. As expected, the neutralizing antibody titers

185 increased after the first and second doses of the Moderna and Pfizer vaccines (Figure

186 1A). The $\mathrm{NT}_{50}$ values for the WHO IS for anti-SARS-CoV-2 immunoglobulin (obtained

187 from NIBSC) were also determined by a live virus neutralization assay (Supplementary

188 Table 1), with linear regression defining the conversion of $\mathrm{NT}_{50}$ values to $\mathrm{IU} / \mathrm{mL}$, as

189 shown in Figure 1B. The GMTs are also shown in Figure 1, illustrating the observed

190 increases. The GMT increased from 157.6 to $1404.16 \mathrm{IU} / \mathrm{mL}$ and from 348.83 to 928.75

$191 \mathrm{IU} / \mathrm{mL}$ for Moderna and Pfizer vaccines, respectively. These GMT values provide a

192 reference for non-inferiority tests of candidate vaccines. 
medRxiv preprint doi: https://doi.org/10.1101/2021.07.16.21260618; this version posted July 22,2021 . The copyright holder for this preprint

(which was not certified by peer review) is the author/funder, who has granted medRxiv a license to display the preprint in perpetuity.

Although the live virus neutralization assay is the gold standard for determining neutralizing antibody titers, the operation is time-consuming and requires a BSL-3

195 laboratory. We developed binding assays to detect anti-S1, anti-RBD, and anti-N antibodies, followed by NIBSC 20/136 (WHO IS) for conversion to BAU/mL (Figure 2). Increases in anti-S1 and anti-RBD antibodies were observed after the first and second doses (Figure 2A and B). Interestingly, anti-N antibodies were detected in a few

199 individuals pre- and post-vaccination, suggesting that the individuals had COVID-19 200 before or after vaccination. To evaluate whether our binding assay based on anti-S1 or anti-RBD in BAU/mL

202 reflects neutralizing antibody titers in $\mathrm{IU} / \mathrm{mL}$, the correlation between the two values 203 was determined, as shown in Figure 2C. Both the S1 and RBD antibody titers were 204 highly correlated with the NT titers ( $r=0.9040$ and 0.9298 , respectively), suggesting 205 that the binding assays based on anti-S1 or RBD can be used as surrogates to measure 206 neutralizing antibodies.

207 All 120 serum samples were tested by commercial serological assays, including 208 the MeDiPro SARS-CoV-2 antibody ELISA, Roche Elecsys ${ }^{\circledR}$ Anti-SARS-CoV-2 S, 209 and Abbott AdviseDx SARS-CoV-2 IgG II assay. Roche and Abbott serological assays 210 are widely used in clinical laboratories to detect SARS-CoV-2 antibodies worldwide. 211 They detect the antibody against the RBD of the S antigen, yielding qualitative and 
medRxiv preprint doi: https://doi.org/10.1101/2021.07.16.21260618; this version posted July 22, 2021. The copyright holder for this preprint (which was not certified by peer review) is the author/funder, who has granted medRxiv a license to display the preprint in perpetuity. All rights reserved. No reuse allowed without permission.

212 semi-quantitative results. MeDiPro is a Taiwan FDA-approved kit for quantifying S1-

213 and RBD-binding antibodies; it assumes that data for S1 and RBD fusion proteins can

214 accurately predict the NT titer. We used real NT titers (IU/mL) from BSL-3 as a

215 standard to assess whether these serological assays reflect the neutralization titers based

216 on the detection of antibodies against S1 and/or RBD. The highest correlation was

217 observed between the titers obtained by the MeDiPro and the live SARS-CoV-2 NT

218 assays ( $r=0.9111)$ (Figure 3A). Roche and Abbott RBD antibody titers also had good

219 correlation coefficients of 0.7294 and 0.8466 , respectively (Figure 3B and C). With

220 respect to the live virus microneutralization assays, the Roche and Abbott serological

221 assays can correctly detect RBD antibodies in all 77 NT-positive samples (Table 1),

222 whereas MeDiPro produced six negative results. Among these six negative results, the

223 NT titer of four samples is equal to $34.47 \mathrm{IU} / \mathrm{mL}$, which is the limit of the detection in

224 MeDiPro assay. Therefore, both the Roche and Abbot serological assays have 100\%

$225(95 \% \mathrm{Cl}, 95.3 \%-100 \%)$ sensitivity, followed by $92.2 \%(95 \% \mathrm{Cl}, 84.0 \%-96.4 \%)$

226 sensitivity for MeDiPro. However, MeDiPro can distinguish a greater proportion of

227 NT-negative samples (40/43) than those of Roche (24/43) and Abbott (25/43). In terms

228 of specificity, MeDiPro achieved a high specificity of $93 \%(95 \% \mathrm{Cl}, 81.4 \%-97.6 \%)$,

229 which was much higher than of the Roche (55.8\% [95\% Cl, 41.1\%-69.6\%]) and Abbott

230 assays $(58.1 \%$ [95\% $\mathrm{Cl}, 43.3 \%-71.6 \%])$. Our results suggest that the MeDiPro SARS- 
medRxiv preprint doi: https://doi.org/10.1101/2021.07.16.21260618; this version posted July 22, 2021. The copyright holder for this preprint (which was not certified by peer review) is the author/funder, who has granted medRxiv a license to display the preprint in perpetuity. All rights reserved. No reuse allowed without permission.

231 CoV-2 neutralization antibody assay is an effective option for detecting SARS-Cov-2

232 neutralizing antibodies without requiring a live virus neutralization assay at a BSL-3

233 laboratory.

234 
medRxiv preprint doi: https://doi.org/10.1101/2021.07.16.21260618; this version posted July 22,2021 . The copyright holder for this preprint

(which was not certified by peer review) is the author/funder, who has granted medRxiv a license to display the preprint in perpetuity.

\section{Discussion}

236 Antibodies increase gradually within a few weeks after vaccination, and the timespan

237 may vary among individuals $(13,14)$. Therefore, it is necessary to test neutralizing

238 antibodies to determine whether protective antibodies will be elevated after vaccination.

239 Vaccinated individuals may still have to take measures to avoid infection. Accordingly,

240 such assays are very important for protecting vaccinated individuals as well as for the

241 control and prevention of epidemics (15).

242 Anti-N antibodies may reveal whether vaccinated individuals were infected by the

243 virus before or after the vaccination dose (16). For example, as shown in Figure 2B,

244 one individual who received the Pfizer vaccine showed a dramatic increase in $\mathrm{N}$ to 556

245 BAU/mL. S1 for the same individual, after the first and second doses, were 2,094 and

$2461,240 \mathrm{BAU} / \mathrm{mL}$, respectively. In the same individual, after the first and second doses,

247 the RBD levels were 1,618 and $927 \mathrm{BAU} / \mathrm{mL}$, respectively. It has been reported that

248 prior infection with SARS-CoV-2 may boost B cells and significantly elevate antibody

249 production $(17,18)$.

250 Roche and Abbott Covid-19 diagnostic kits are being used extensively in clinical

251 laboratories (19-21). They are semi-quantitative and were originally designed to

252 confirm an infected case. In this study, we utilized standard sera to develop an approach

253 that utilizes these two kits to quantitate antibody titers after vaccination. The Pearson's 
medRxiv preprint doi: https://doi.org/10.1101/2021.07.16.21260618; this version posted July 22,2021 . The copyright holder for this preprint

(which was not certified by peer review) is the author/funder, who has granted medRxiv a license to display the preprint in perpetuity.

All rights reserved. No reuse allowed without permission.

254 correlation coefficients $(r)$ between these antibody titers and neutralization antibody

255 titers were 0.7294 and 0.8466 , respectively. Titers obtained by MeDiPro, designed to

256 detect neutralizing antibody titers, were highly correlated with titers obtained by live

257 SARS-CoV-2 NT assays $(r=0.9111)$.

IS was used to obtain neutralizing antibody titers in IU/mL and binding antibody

259 titers in BAU/mL. We obtained GMTs of 1404.16 and 928.75 for neutralizing

260 antibodies in serum samples from recipients of Moderna and Pfizer vaccines $(\mathrm{n}=20$

261 each) after two doses, respectively. These estimates may provide important information

262 for vaccine developers implementing non-inferiority tests. Moreover, we compared

263 three commercially available kits used for the detection of COVID-19 antibodies based

264 on binding affinities to S1 and/or RBD. Our results demonstrated that antibody titers

265 measured by commercial assays are strongly correlated with neutralizing antibody titers

266 via IS calibration.

\section{Acknowledgements}

269 This work was financially supported by the Research Center for Emerging Viral

270 Infections from The Featured Areas Research Center Program within the framework of

271 the Higher Education Sprout Project by the Ministry of Education (MOE), Taiwan, the

272 Ministry of Science and Technology (MOST), Taiwan (MOST 109-2634-F-182-001 
medRxiv preprint doi: https://doi.org/10.1101/2021.07.16.21260618; this version posted July 22,2021 . The copyright holder for this preprint (which was not certified by peer review) is the author/funder, who has granted medRxiv a license to display the preprint in perpetuity. All rights reserved. No reuse allowed without permission.

273 and 109-2221-E-182-043-MY2), the Research Center for Epidemic Prevention Science

274 by the MOST, Taiwan (MOST 109-2327-B-182-002), the Chang Gung Memorial

275 Hospital (grant number BMRP367), and the National Institutes of Health USA grant

276 U01 AI151698 for the United World Antiviral Research Network (UWARN).

278 Author contributions

279 C.G.H, G.W.C. and S.R.S. designed the experiments. Y.A.K., S.Y.H., P.N.H., Y.T.L. 280 and Y.C.L. conducted the live virus neutralization assay at BSL3 facility. K.T.L., 281 K.Y.Y., S.L.Y., C.P.C. and C.Y.C conducted the serological assay. Y.A.K., S.Y.H., 282 K.T.L. and C.G.H. analyzed the data. Y.A.K., K.T.L., G.W.C. and S.R.S. wrote the 283 manuscript.

\section{Declaration}

286 MeDiPro SARS-CoV-2 antibody ELISA was technology transferred from Research

287 Center for Emerging Viral Infections, Chang Gung University, Taiwan. We herewith

288 declare that MeDiPro, Roche, and Abbott did not financially support any research in

289 Research Center for Emerging Viral Infections, Chang Gung University and Chang

290 Gung Memorial Hospital, Taiwan. 
medRxiv preprint doi: https://doi.org/10.1101/2021.07.16.21260618; this version posted July 22,2021 . The copyright holder for this preprint (which was not certified by peer review) is the author/funder, who has granted medRxiv a license to display the preprint in perpetuity.

\section{References}

293 1. Khoury DS, Cromer D, Reynaldi A, Schlub TE, Wheatley AK, Juno JA,

Subbarao K, Kent SJ, Triccas JA, Davenport MP. 2021. Neutralizing antibody levels are highly predictive of immune protection from symptomatic SARSCoV-2 infection. Nat Med doi:10.1038/s41591-021-01377-8. immunity: a longitudinal study. Lancet Microbe 2:e240-e249. for COVID-19 vaccines. Vaccine 39:4423-4428. antibody by wild-type plaque reduction neutralization, microneutralization and 
medRxiv preprint doi: https://doi.org/10.1101/2021.07.16.21260618; this version posted July 22, 2021. The copyright holder for this preprint (which was not certified by peer review) is the author/funder, who has granted medRxiv a license to display the preprint in perpetuity. All rights reserved. No reuse allowed without permission.

311 5. Supasa P, Zhou D, Dejnirattisai W, Liu C, Mentzer AJ, Ginn HM, Zhao Y, Duyvesteyn HME, Nutalai R, Tuekprakhon A, Wang B, Paesen GC, SlonCampos J, Lopez-Camacho C, Hallis B, Coombes N, Bewley KR, Charlton S, Walter TS, Barnes E, Dunachie SJ, Skelly D, Lumley SF, Baker N, Shaik I, Humphries HE, Godwin K, Gent N, Sienkiewicz A, Dold C, Levin R, Dong T, Pollard AJ, Knight JC, Klenerman P, Crook D, Lambe T, Clutterbuck E, Bibi S, Flaxman A, Bittaye M, Belij-Rammerstorfer S, Gilbert S, Hall DR, Williams MA, Paterson NG, James W, Carroll MW, Fry EE, Mongkolsapaya J, et al. 2021. Reduced neutralization of SARS-CoV-2 B.1.1.7 variant by convalescent and vaccine sera. Cell 184:2201-2211 e7.

321 6. WHO/BS.2020.2403. 2020. Establishment of the WHO International Standard and Reference Panel for anti-SARS-CoV-2 antibody.

323 7. WHO/BS.2020.2402. 2020. Collaborative Study for the Establishment of a WHO International Standard for SARS-CoV-2 RNA.

325 8. Kristiansen PA, Page M, Bernasconi V, Mattiuzzo G, Dull P, Makar K, Plotkin S, Knezevic I. 2021. WHO International Standard for anti-SARSCoV-2 immunoglobulin. Lancet 397:1347-1348. 
medRxiv preprint doi: https://doi.org/10.1101/2021.07.16.21260618; this version posted July 22, 2021. The copyright holder for this preprint (which was not certified by peer review) is the author/funder, who has granted medRxiv a license to display the preprint in perpetuity.

SARS-CoV-2 surrogate virus neutralization test based on antibody-mediated

blockage of ACE2-spike protein-protein interaction. Nat Biotechnol 38:1073-

1078.

10. Patel EU, Bloch EM, Clarke W, Hsieh YH, Boon D, Eby Y, Fernandez RE,

Baker OR, Keruly M, Kirby CS, Klock E, Littlefield K, Miller J, Schmidt HA,

Sullivan P, Piwowar-Manning E, Shrestha R, Redd AD, Rothman RE,

Laeyendecker O. 2021. Comparative Performance of Five Commercially

Available Serologic Assays To Detect Antibodies to SARS-CoV-2 and

340 11. Huynh A, Arnold DM, Smith JW, Moore JC, Zhang A, Chagla Z, Harvey BJ,

344 12. Kyriakidis NC, Lopez-Cortes A, Gonzalez EV, Grimaldos AB, Prado EO.

2021. SARS-CoV-2 vaccines strategies: a comprehensive review of phase 3

candidates. NPJ Vaccines 6:28.

347 13. Goel RR, Apostolidis SA, Painter MM, Mathew D, Pattekar A, Kuthuru O, 
medRxiv preprint doi: https://doi.org/10.1101/2021.07.16.21260618; this version posted July 22, 2021. The copyright holder for this preprint (which was not certified by peer review) is the author/funder, who has granted medRxiv a license to display the preprint in perpetuity.

Kuri-Cervantes L, Adamski S, Hicks A, Korte S, Oldridge DA, Baxter AE,

Giles JR, Weirick ME, McAllister CM, Dougherty J, Long S, D'Andrea K,

Hamilton JT, Betts MR, Luning Prak ET, Bates P, Hensley SE, Greenplate

AR, Wherry EJ. 2021. Distinct antibody and memory B cell responses in

SARS-CoV-2 naive and recovered individuals following mRNA vaccination.

Sci Immunol 6.

14. Pollard AJ, Bijker EM. 2021. A guide to vaccinology: from basic principles to new developments. Nat Rev Immunol 21:83-100.

15. Bartsch SM, O'Shea KJ, Ferguson MC, Bottazzi ME, Wedlock PT, Strych U,

Epidemic as the Sole Intervention. Am J Prev Med 59:493-503.

16. Diao B, Wen K, Zhang J, Chen J, Han C, Chen Y, Wang S, Deng G, Zhou H,

Wu Y. 2021. Accuracy of a nucleocapsid protein antigen rapid test in the

17. Reynolds CJ, Pade C, Gibbons JM, Butler DK, Otter AD, Menacho K, 
medRxiv preprint doi: https://doi.org/10.1101/2021.07.16.21260618; this version posted July 22, 2021. The copyright holder for this preprint (which was not certified by peer review) is the author/funder, who has granted medRxiv a license to display the preprint in perpetuity. All rights reserved. No reuse allowed without permission.

DM, Boyton R. 2021. Prior SARS-CoV-2 infection rescues B and T cell doi:10.1126/science.abh1282.

371 18. Anichini G, Terrosi C, Gandolfo C, Gori Savellini G, Fabrizi S, Miceli GB, Cusi MG. 2021. SARS-CoV-2 Antibody Response in Persons with Past Natural Infection. N Engl J Med 385:90-92.

19. Tan SS, Saw S, Chew KL, Wang C, Pajarillaga A, Khoo C, Wang W, Ali ZM, 
medRxiv preprint doi: https://doi.org/10.1101/2021.07.16.21260618; this version posted July 22, 2021. The copyright holder for this preprint (which was not certified by peer review) is the author/funder, who has granted medRxiv a license to display the preprint in perpetuity.

\section{Figures and Tables}

A

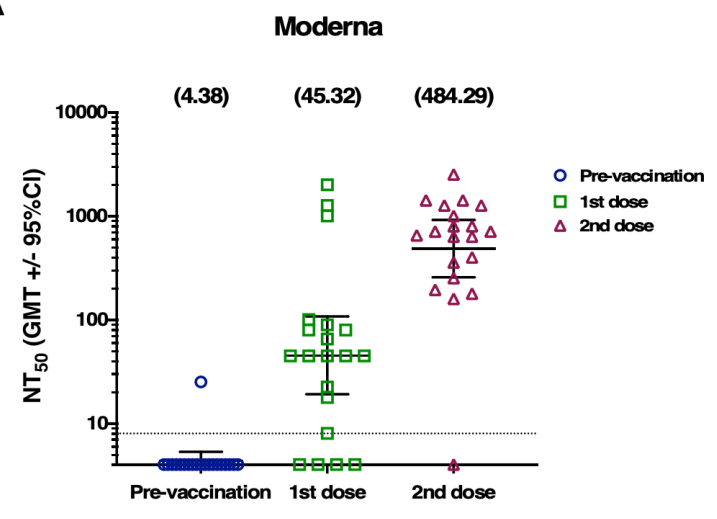

B

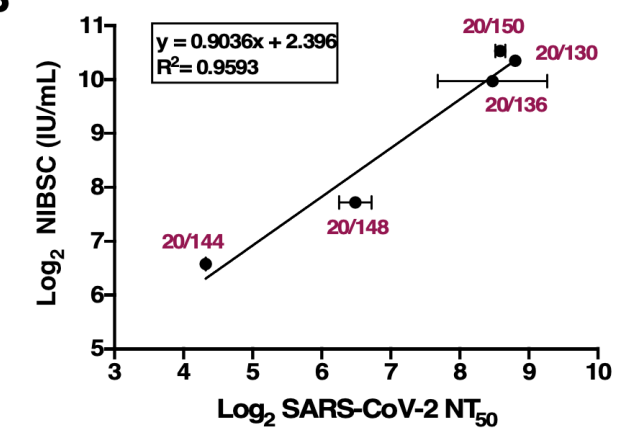

C

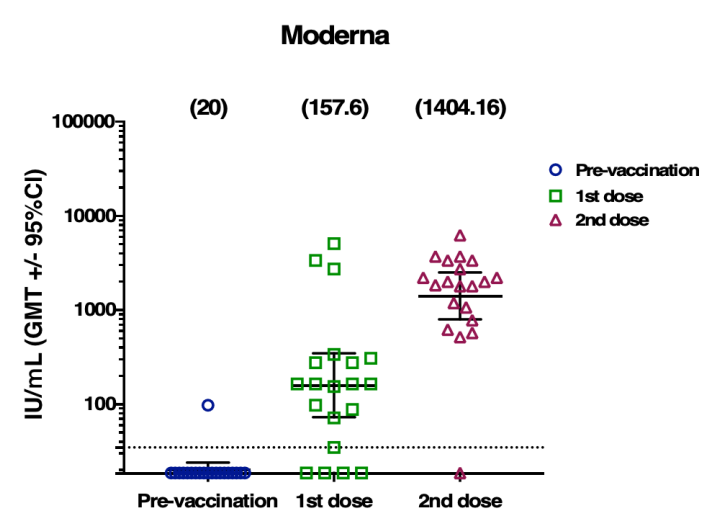

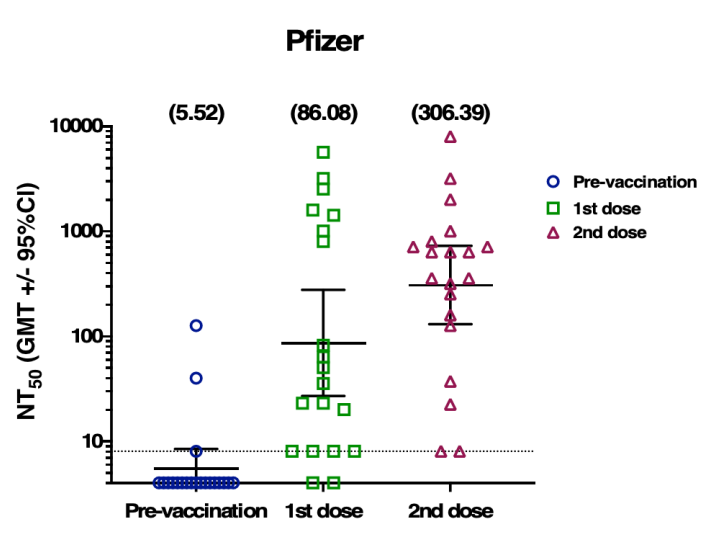

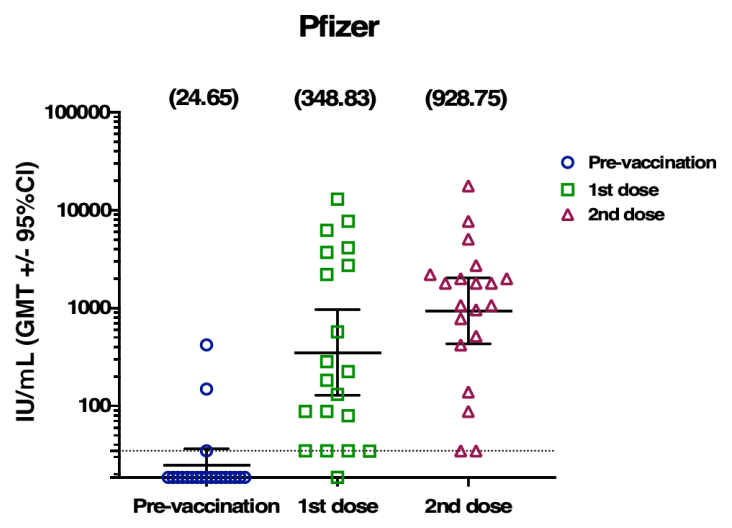

390 Figure 1. Neutralization serum titers in vaccinated individuals

391 (A) $\mathrm{NT}_{50}$ values for 120 serum samples from 20 recipients of Moderna mRNA-1273

392 and 20 recipients of Pfizer BNT162b2. (B) The calibration curve (standard curve) used 
medRxiv preprint doi: https://doi.org/10.1101/2021.07.16.21260618; this version posted July 22, 2021. The copyright holder for this preprint

(which was not certified by peer review) is the author/funder, who has granted medRxiv a license to display the preprint in perpetuity.

All rights reserved. No reuse allowed without permission.

393 for the conversion of $\mathrm{NT}_{50}$ values to the international standard units (IU/mL). Presented

394 are the results from an experiment in technical duplicate and error bars show the SD.

395 (C) The IU value for 120 serum samples (20 for the Moderna mRNA-1273 group and

39620 for the Pfizer BNT162b2 group). The geometric mean titers (GMTs) with $95 \%$ CI

397 are shown pre-vaccination, after the first dose, and after the second dose.

398 
medRxiv preprint doi: https://doi.org/10.1101/2021.07.16.21260618; this version posted July 22, 2021. The copyright holder for this preprint (which was not certified by peer review) is the author/funder, who has granted medRxiv a license to display the preprint in perpetuity.

\section{A Moderna}
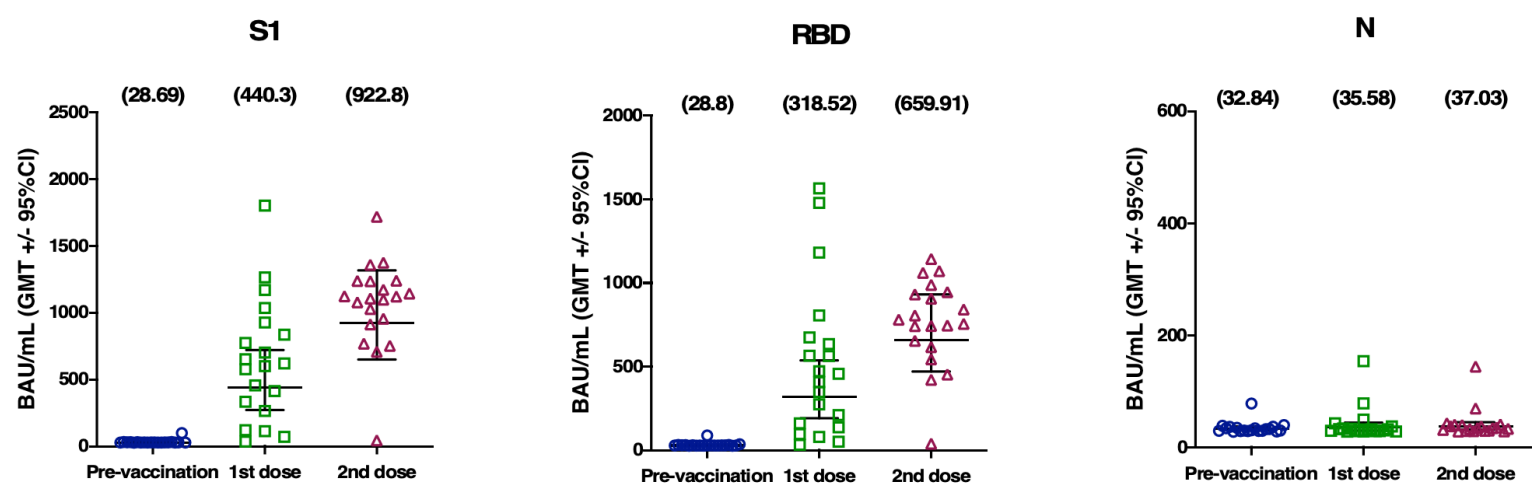

\section{B Pfizer}
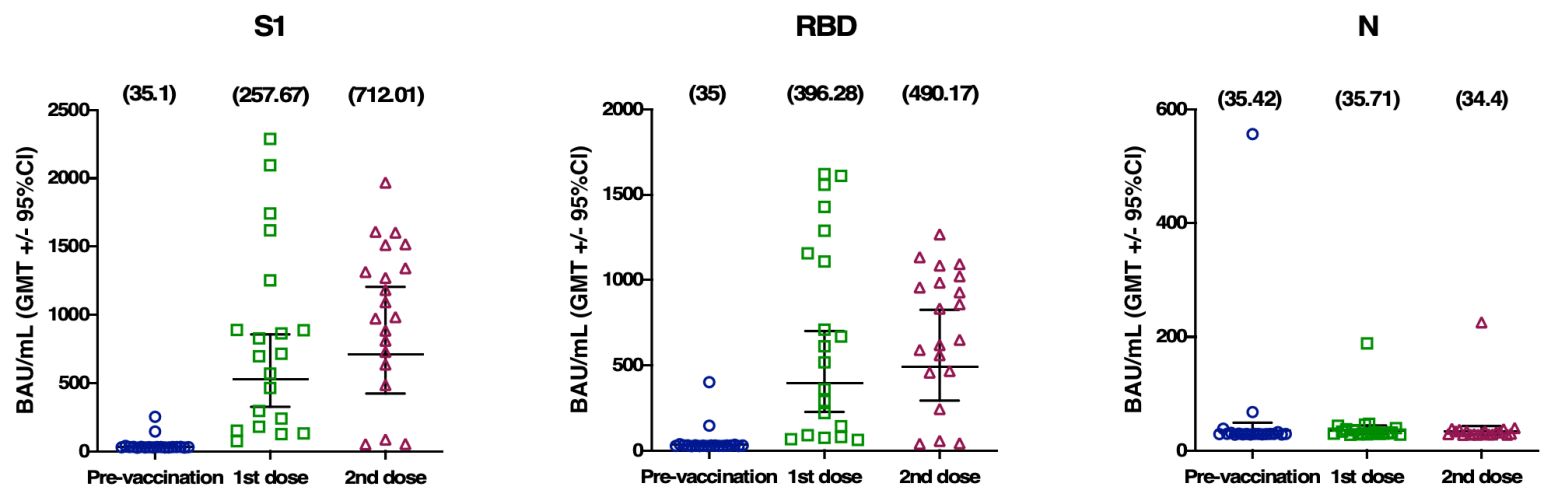

C

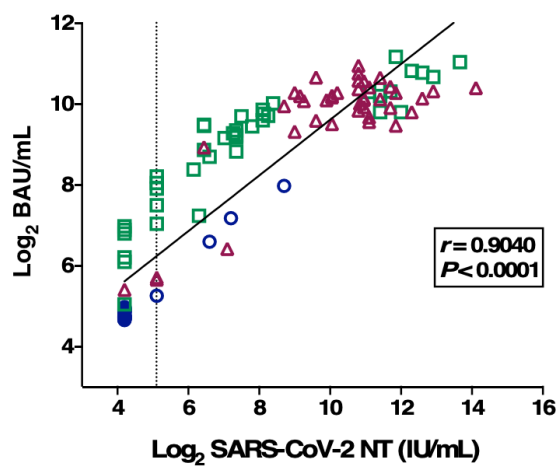

O Pre-vaccination

1st dose

$\triangle$ 2nd dose
S1

Figure 2. Antibody response in $\mathbf{1 2 0}$ serum samples from vaccinated individuals.

402 The responses of antibodies against S1, RBD, and N protein were detected in 120 serum

403 samples from 20 individuals receiving Moderna mRNA-1273 (A) and 20 individuals 
medRxiv preprint doi: https://doi.org/10.1101/2021.07.16.21260618; this version posted July 22, 2021. The copyright holder for this preprint (which was not certified by peer review) is the author/funder, who has granted medRxiv a license to display the preprint in perpetuity. All rights reserved. No reuse allowed without permission.

404 receiving Pfizer BNT162b2 vaccines (B). The geometric mean titers (GMTs) with 95\%

405 CI are shown pre-vaccination, after the first dose, and after the second dose. (C)

406 Correlation between the live virus neutralization titer (IU/mL) and antibody binding

407 unit $(\mathrm{BAU} / \mathrm{mL})$ in 120 serum samples. Vertical dashed lines indicate the limit of

408 detection $(\mathrm{NT}=34.47)$. The Pearson's correlation coefficients $(r)$ are provided for S1

409 or RBD antibody responses to live virus neutralization titer (IU/mL). 
A

MeDiPro

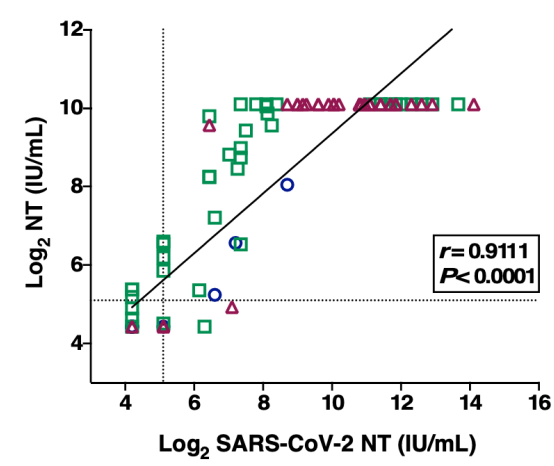

C
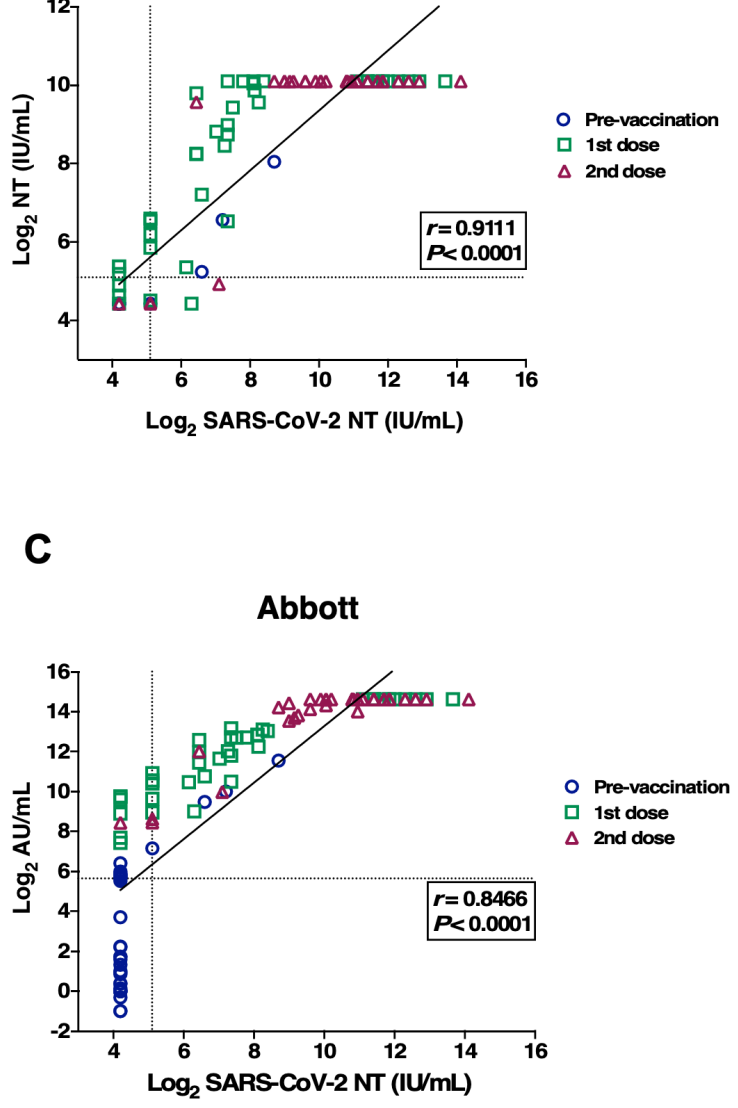

$\square$ 1st dose
$\triangle$ 2nd dose

B

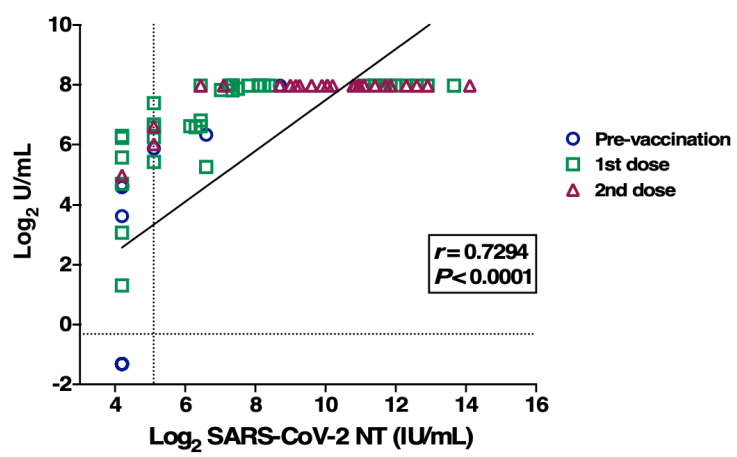

Roche

412

Figure 3. Correlation analysis of commercial serological assays against SARS-

\section{CoV-2 neutralizing antibody titers.}

415 Correlations between titers obtained by MeDiPro SARS-CoV-2 antibody ELISA (A),

416 Roche Elecsys ${ }^{\circledR}$ Anti-SARS-CoV-2 S assay (B), and Abbott AdviseDx SARS-CoV-2

417 IgG II assay (C) and live SARS-CoV-2 neutralization titers (IU/mL). The vertical

418 dashed line indicates the limit of detection $(\mathrm{NT}=34.47 \mathrm{IU} / \mathrm{mL})$. The horizontal dashed

419 lines indicate the cut-off values for MeDiPro (34.47 IU/mL), Roche $(0.80 \mathrm{U} / \mathrm{mL})$, and

420 Abbott (50.0 AU/mL). Correlations were performed in the Pearson's correlation

421 coefficients $(r)$. 
medRxiv preprint doi: https://doi.org/10.1101/2021.07.16.21260618; this version posted July 22,2021 . The copyright holder for this preprint (which was not certified by peer review) is the author/funder, who has granted medRxiv a license to display the preprint in perpetuity.

422 Table 1. Comparison of commercial serological assays with SARS-CoV-2 neutralizing antibody titer

\begin{tabular}{|c|c|c|c|c|c|c|c|}
\hline \multirow{2}{*}{\multicolumn{2}{|c|}{$\begin{array}{c}\text { Total samples (120) } \\
\text { Real NT }\end{array}$}} & \multicolumn{2}{|c|}{ MeDiPro } & \multicolumn{2}{|c|}{ Roche } & \multicolumn{2}{|c|}{ Abbott } \\
\hline & & \multirow{2}{*}{$\begin{array}{c}\text { Positive } \\
71\end{array}$} & \multirow{2}{*}{$\begin{array}{c}{ }^{\mathrm{b}} \text { Negative } \\
{ }^{\Psi} 6\end{array}$} & \multirow{2}{*}{$\begin{array}{c}\text { Positive } \\
77\end{array}$} & \multirow{2}{*}{$\begin{array}{c}{ }^{\mathrm{c}} \text { Negative } \\
0\end{array}$} & \multirow{2}{*}{$\begin{array}{c}\text { Positive } \\
77\end{array}$} & \multirow{2}{*}{$\begin{array}{c}{ }^{\mathrm{d}} \text { Negative } \\
0\end{array}$} \\
\hline Positive & 77 & & & & & & \\
\hline${ }^{\text {anNegative }}$ & 43 & 3 & 40 & 19 & 24 & 18 & 25 \\
\hline \multicolumn{2}{|c|}{ Sensitivity $=\mathrm{TP} /(\mathrm{TP}+\mathrm{FN})$} & \multicolumn{2}{|c|}{$92.2 \%(84.0 \%-96.4 \%)$} & \multicolumn{2}{|c|}{$100 \%(95.3 \%-100 \%)$} & \multicolumn{2}{|c|}{$100 \%(95.3 \%-100 \%)$} \\
\hline \multicolumn{2}{|c|}{ Specificity=TN/(TN+FP) } & \multicolumn{2}{|c|}{$93.0 \%(81.4 \%-97.6 \%)$} & \multicolumn{2}{|c|}{$55.8 \%(41.1 \%-69.6 \%)$} & \multicolumn{2}{|c|}{$58.1 \%(43.3 \%-71.6 \%)$} \\
\hline \multicolumn{2}{|c|}{$\mathrm{PPV}=\mathrm{TP} /(\mathrm{TP}+\mathrm{FP})$} & \multicolumn{2}{|c|}{$95.9 \%(85.8 \%-98.9 \%)$} & \multicolumn{2}{|c|}{$80.2 \%(71.1 \%-87.0 \%)$} & \multicolumn{2}{|c|}{$81.1 \%(72.0 \%-87.7 \%)$} \\
\hline \multicolumn{2}{|c|}{$\mathrm{NPV}=\mathrm{TN} /(\mathrm{TN}+\mathrm{FN})$} & \multicolumn{2}{|c|}{$87.0 \%$ (74.3\%-93.9\%) } & \multicolumn{2}{|c|}{$100 \%(86.2 \%-100 \%)$} & \multicolumn{2}{|c|}{$100.0 \%(86.7 \%-100 \%)$} \\
\hline
\end{tabular}

424 TP, true positive; FP, false positive; TN, true negative; FN, false negative; PPV,

425 positive predictive value; NPV, negative predictive value

426 a, b Negative $<34.37 \mathrm{IU} / \mathrm{mL}$

$427 \quad{ }^{\mathrm{c}}$ Negative $<0.80 \mathrm{U} / \mathrm{mL}$

$428{ }^{\mathrm{d}}$ Negative $<50.0 \mathrm{AU} / \mathrm{mL}$

$429{ }^{\Psi}$ Among the six negative samples, four samples have a neutralizing antibody titer of

$430 \quad 34.37 \mathrm{IU} / \mathrm{mL}$. 
medRxiv preprint doi: https://doi.org/10.1101/2021.07.16.21260618; this version posted July 22,2021 . The copyright holder for this preprint (which was not certified by peer review) is the author/funder, who has granted medRxiv a license to display the preprint in perpetuity. All rights reserved. No reuse allowed without permission.

\section{Supplementary information}

\section{Supplementary Table 1 . The $\mathbf{N T}_{50}$ values of WHO international standard sera}

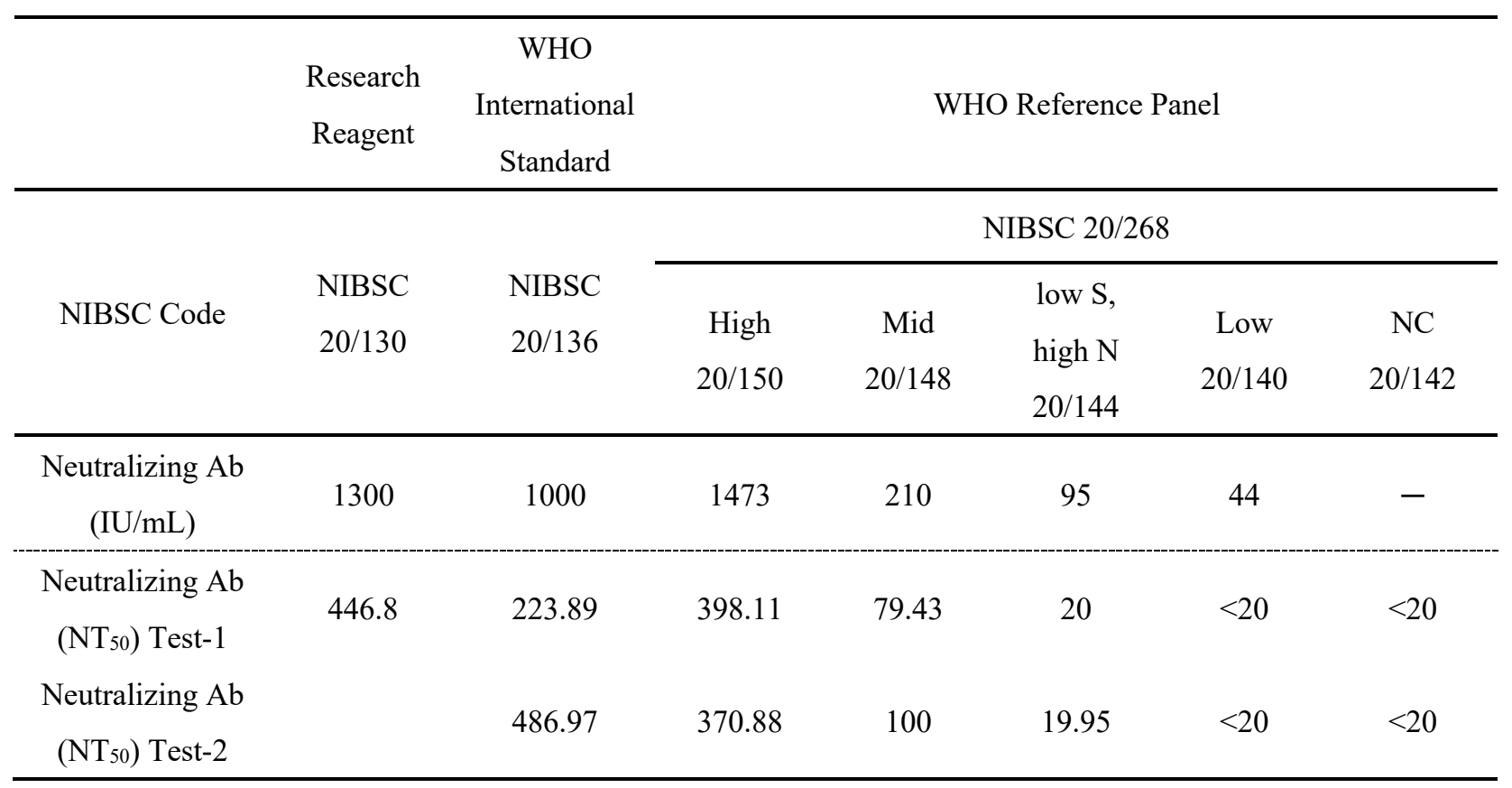

436 NIBSC, National Institute for Biological Standards and Control; $\mathrm{NT}_{50}, 50 \%$

437 neutralization titer 